[RAdiocarbon, Vol. 8, 1966, P. 286-291]

\title{
MONACO RADIOCARBON MEASUREMENTS II
}

\section{J. THOMMERET and Y. THOMMERET}

Centre Scientifique de Monaco

This series reports some of the measurements made since publication of the previous list. Chemical preparation of samples is basically the same as described in Monaco I.

The counting electronics of the proportional counter has been entirely rebuilt by J. Galliot and P. Albertinoli of C.S.M. The new device is transistorized and battery-operated. At regular intervals of time, usually $10 \mathrm{~min}$, the count (anti-coincidence channel) is printed in tape. Large deviations from the mean are easily visible and can lead to rejection of the measurement if the distribution is not normal, i.e. does not fit a straight line on Gaussian paper.

No $\delta \mathrm{C}^{13}$ measurements have been made, and carbonate substances are dated by reference to the standard without correction. All the ages have been calculated using the formula

$$
\mathrm{T}=-\frac{\mathrm{t} 1 / 2}{\ln 2} \ln \left(1+10^{-3} \times \delta \mathrm{C}^{14}\right)
$$

where $\delta \mathrm{C}^{14}=\frac{\text { Sample Activity }-0.95 \text { NBS Activity }}{0.95 \text { NBS Activity }} \times 1000$

$\mathrm{C}^{14}$ half life value $\mathrm{t} 1 / 2=5568 \pm 30 \mathrm{yr}$. The reference year is 1950 .

Precision measurements are given with one standard deviation, calculated by combining deviations of the unknown sample, the background and the modern sample, these last two taken over a period of several weeks with at least three independent fillings. When the net sample activity, with a standard deviation $\sigma$, is less than $2 \sigma$ above the background, an infinite age is reported, and when the activity is greater than $0.95 \mathrm{NBS}$ minus $2 \sigma$, a modern date is given.

Besides the dates reported here, a series of ten measurements has been made of $\mathrm{C}^{14}$ content of surface and deep sea-water of the north Indian Ocean, collected in 1963 (Thommeret and others, 1965).

\section{SAMPLE DESCRIPTIONS}

I. GEOLOGIC SAMPLES

\section{A. France}

\section{Beaulieu Canyon series, Alpes Maritimes}

Three samples taken in May 1961 in Beaulieu submarine canyon, from R/V Winnaretta Singer. Coll. and subm. by M. Gennesseaux, Lab. de Géog. Physique et Géol. Dynamique, Faculté des Sci. Paris.

\section{MC-22. Beaulieu Canyon 1}

$18,200 \pm 1000$

Piece of bryozoan, $12 \mathrm{~mm}$ diam, taken in core no. $123\left(43^{\circ} 34^{\prime} \mathrm{N}\right.$ Lat, $7^{\circ} 26^{\prime} \mathrm{E}$ Long), $1080 \mathrm{~m}$ depth in axis of canyon. 
MC-24. Beaulieu Canyon 2

$22,800 \pm 1000$

20,850 B.c.

Compact ooze from canyon wall taken at $1950 \mathrm{~m}$ depth, dredging no. 677 ( $43^{\circ} 38^{\prime} \mathrm{N}$ Lat, $7^{\circ} 27^{\prime} \mathrm{E}$ Long). Grain-size fractions are 0.25 to $0.08 \mathrm{~mm}$.

\section{MC-25. Beaulieu Canyon 3}

$20,300 \pm 1000$

White, very compact bottom ooze, dredging no. 677. Grain-size fractions are 0.25 to $0.08 \mathrm{~mm}$.

General Comment (M.G.) : measurements show a type of sedimentation essentially pelagic on the continental slope during Würmian period and prove recent submarine erosion involving formation of some canyons; MC-22 suggests outcrop of old compact deposits in head of canyon and their erosion by slumping.

\section{Monaco series}

\section{MC-52. Monaco 1}

$$
\begin{aligned}
& 21,000 \pm 1000 \\
& 19,050 \text { B.c. }
\end{aligned}
$$

Shells of Piteria chione $\mathrm{L}$. from sea-deposit at $+2.5 \mathrm{~m}$ above present sealevel, found near $S$ entrance of road tunnel under Rock of Monaco (43 43' 50" N Lat, 7 25' 3" E Long). Coll. 1957 by members of Assoc. de Préhistoire et de Spèléologie; subm. by L. Barral, Conservator of Musée d'Anthropol. Préhistorique de Monaco.

\section{MC-53. Monaco 2}

$16,600 \pm 700$

Organic matter from sandy tubes ("Hermelle") of the polychace worm Sabellaria alveolata (L.). Coll, as MC-52 Comment (L.) : MC-52 and MC-53 may date a sealevel of last interstadial Würmian period $\left(\mathrm{W}_{\mathrm{III}}-\mathrm{W}_{\mathrm{IV}}\right)$.

\section{MC-54. Monaco 3}

Big shell of Spondylus gaederopus L. from colony found in small rocky cavity at $+16 \mathrm{~m}$ level, in the course of grading works, Boulevard Charles III (43 $43^{\prime} 52^{\prime \prime}$ N Lat, $7^{\circ} 24^{\prime} 52^{\prime \prime}$ E Long). Coll. by Travaux Publics de Monaco; subm. by L. Barral. Comment: date given is that of carbonate fraction, but no deduction can be drawn, as there is a large difference of age (more than 15,000 yr) between internal and external parts of the shell.

\section{MEDITERRANEAN OPEN-SEA CORES}

Samples from two piston-cores, taken at area distant from coast in western basin of Mediterranean Sea. Coll. summer 1962 from R/V Calypso; subm. by J. Ros, Centre des Faibles Radioactivités, C.N.R.S., Gif sur Yvette, (S. \& O.), France. 


\section{Core no. 16 series}

Taken at depth $2460 \mathrm{~m}\left(41^{\circ} 22^{\prime} \mathrm{N}\right.$ Lat, $05^{\circ} 53.5^{\prime} \mathrm{E}$ Long), sedimentary column is $170 \mathrm{~cm}$ long and shows two layers: an upper yellow mud $(0$ to $117 \mathrm{~cm})$, overlying sand $(117$ to $170 \mathrm{~cm})$. Two foraminiferan layers are found in mud portion at 14 and $60 \mathrm{~cm}$. Ca. $42 \% \mathrm{CaCO}_{3}$. The coarse fraction $(>40 \mu)$ is below $10 \%$ and composed of shells of foraminifera. Deeper sand appears homogeneous in grain size and the coarse fraction is almost constant. All samples analyzed are bulk $\mathrm{CaCo}_{3}$ from mud section.

MC-27. C 16, 0-10 cm

MC-28. C 16, 17-25 cm

MC-29. C 16, 47-56 cm
$3400 \pm 200$

$$
1450 \text { B.c. }
$$

$6350 \pm 300$

4400 в.C.

$13,200 \pm 470$

11,250 в.C.

$25,700 \pm 1400$

23,750 B.c.

MC-30. C 16, 100-108 cm

Comment (J.R.) : MC-27 value agrees with results obtained at C.F.R. (Saclay I). As reworked carbonate may have been present, age should be considered maximum. Sedimentation rate is markedly constant: 5 to 21 $\mathrm{cm}, 5.3 \mathrm{~cm} / 1000 \mathrm{yr} ; 21$ to $51 \mathrm{~cm}, 4.3 \mathrm{~cm} / 1000 \mathrm{yr} ; 51$ to $104 \mathrm{~cm}, 4.2$ $\mathrm{cm} / 1000 \mathrm{yr}$.

\section{Core no. 18 series}

Taken at depth $2525 \mathrm{~m}\left(41^{\circ} 02.5^{\prime} \mathrm{N}\right.$ Lat, $05^{\circ} 35.5^{\prime} \mathrm{E}$ Long). Sedimentary column of $88 \mathrm{~cm}$ long is composed of yellow mud, containing foraminiferan and pteropod layers. Average content of $\mathrm{CaCO}_{3}$ is $53 \%$. Coarse fraction averages $14 \%$ and is composed of shells of foraminifera and pteropods. All $\mathrm{C}^{14}$ analysis made on the bulk $\mathrm{CaCo}_{3}$.

\section{MC-31. C 18, 0-4 cm \\ MC-32. C 18, $21-27 \mathrm{~cm}$}

$3050 \pm 220$

1100 B.C.

$6250 \pm 200$ 4300 в.C.

$$
6960 \pm 200
$$$$
5010 \text { B.c. }
$$$$
9840 \pm 400
$$

7890 B.c.

MC-34. C 18, 60-66 cm

General Comment (J.R.) : MC-31 value of surface layer 0 to $4 \mathrm{~cm}$ similar to MC-27. Sedimentation rate is very irregular as in most other Mediterranean cores but unlike core no. 16: 2 to $24 \mathrm{~cm}, 6.8 \mathrm{~cm} / 1000 \mathrm{yr} ; 24$ to $46 \mathrm{~cm}, 31.0 \mathrm{~cm} / 1000 \mathrm{yr} ; 46$ to $63 \mathrm{~cm}, 5.8 \mathrm{~cm} / 1000 \mathrm{yr}$. 


\section{Lebanon littoral series, Tabarja}

\section{B. Lebanon}

The Lebanon shore shows, all along its rocky limestone coast, a peculiar facies called "le trottoir" (the bench), constituted by tabular agglomerates of sessile gastropod mollusks, Vermetus sp. At coast NE of Beirut, between Nahr Ibrahim River and Bay of Jounieh, a raised blackish bench lies behind infra-littoral bench, at ca. $1 \mathrm{~m}$ above present sealevel. Upheaval of higher bench seems to result from a recent tectonic movement, as suggested by remains of pottery and tiles found in the dead bioherm. Samples coll. Oct. 1964 and subm. by M. Fevret, Lab. de Géog. d'Aix, France, and P. Sanlaville, Inst. de Géog. de Beyrouth, Lebanon.

\section{MC-63. Tabarja 1}

MC-64. Tabarja 2
$1635 \pm 130$ A.D. 315

$$
1560 \pm 140
$$

\section{A.D. 390}

MC-63 and MC-64: fossil shells of Dendropoma petraeum (Monterosato) from upper bench of Tabarja (34 $02^{\prime} \mathrm{N}$ Lat, $35^{\circ} 37^{\prime} \mathrm{E}$ Long).

\section{MC-65. Tabarja 3}

$\delta \mathrm{C}^{14}=+19 \pm 13 \%$

Shells of living Dendropoma taken at Bouar Tabarja $\left(34^{\circ} 03^{\prime} \mathrm{N}\right.$ Lat, $35^{\circ} 37^{\prime}$ E Long) on present mediolittoral bench.

General Comment (M.F. and P.S.) : age found for MC-63 and MC-64 confirms that upheaval of higher bench is related to one of the seisms which affected Lebanon shore in late Roman Empire or early medieval time and may correspond to earthquake that destroyed Beirut in A.D. 551 . MC- 65 shows enrichment of the biocenosis by recent $\mathrm{C}^{14}$ bomb effects. Thus no correction needed for MC-63 and MC-64.

\section{Viet Nam}

\section{MC-60. Glacière de Cholon}

$12,230 \pm 270$

Wood from $68.6 \mathrm{~m}$ depth below surface in boring in "Glacière de Cholon" (Quaternary alluvium of Donnaī delta), Saīgon, South Viet Nam (10 $45^{\prime} \mathrm{N}$ Lat, $106^{\circ} 39^{\prime} \mathrm{E}$ Long). Coll. 1962 and subm. by E. Saurin, Univ. of Saigon, Viet Nam. Comment (E.S.) : age shows rapid filling in area, considered to be part of Mekong-Donnai delta since the end of Würm.

\section{ARCHAEOLOGIC SAMPLES}

\section{A. France}

\section{MC-55. Beaulieu sur Mer, Alpes Maritimes}

Carbonaceous earth from a well-characterized fireplace $(2 \mathrm{~m}$ long, $30 \mathrm{~cm}$ thick) found at $4 \mathrm{~m}$ below present ground level, on a paleosol from an interstadial Würmian loess deposit (probably $\mathrm{W}_{\mathrm{II}}-\mathrm{W}_{\mathrm{III}}$ ). This paleosol, included in a defined stratigraphy, is overlain by strongly red- 
dened clay layer, another paleosol spotted with pseudo-mycelium $(2 \mathrm{~m}$ thick), and present ground, Beaulieu sur Mer $\left(43^{\circ} 42^{\prime} 9^{\prime \prime} \mathrm{N}\right.$ Lat, $7^{\circ} 11^{\prime}$ 40" E Long). Coll. 1961 and subm. by G. Iaworsky, Musée d'Anthropol. Préhistorique de Monaco. Comment (G.I.): date confirms human occupation in area at very early epoch.

\section{MC-81. Annecy lacustrine city, Haute Savoie}

Section of hard Quercus wood, diam 2 in., found in Lake of Annecy; from "Palafitte" ("Lake Dwellers") city of Roselet, near Duingt ( $45^{\circ}$ $50^{\prime} \mathrm{N}$ Lat, $6^{\circ} 10^{\prime}$ E Long). Coll. June 1963 and subm. by Dr. P. Servettaz. Comment: date, though very young, could correspond to late Alpine Bronze Age and thus agree with expectation (Blanchard, 1958, p. 31-33) .

\section{Hang Gon series}

\section{B. Viet Nam}

Two samples of charcoal found in field of burial urns (used for cremation burials) on archaeological site of Hang Gon, near Xuan Loc, South Viet Nam (10 $48^{\prime}$ N Lat, $107^{\circ} 15^{\prime}$ E Long). Coll. Jan. 1963 and subm. by E. Saurin.

\section{MC-61. Hang Gon 1}

$2190 \pm 150$

Charcoal found in Jar no. 1.

240 B.c.

\section{MC-62. Hang Gon 2}

$2300 \pm 150$

Charcoal found around jars.

General Comment (E.S.) : it is reasonable to suppose that these samples of charcoal were contemporaneous with the jars, in or around which they were found. Their age supplies date for "Sa Yuinh" culture which developed on S coast of Viet Nam and influenced neighbouring regions of Philippines and Malaya. Archaeological estimates indicated date near the beginning of the Christian era, and are confirmed.

\section{ATMOSPHERIC RADIOCARBON}

\section{Atmospheric radiocarbon series, Monaco}

The following list covers samples of atmospheric $\mathrm{CO}_{2}$ measured since 1962 to determine increase of $\mathrm{C}^{14}$ in air. For each measurement $2 \mathrm{~L} 0.5 \mathrm{~N}$ carbonate-free $\mathrm{NaOH}$ are exposed to atmospheric $\mathrm{CO}_{2}$ for 5 days, in a plastic tray on terrace of Musée Océanographique de Monaco $\left(43^{\circ} 43^{\prime} \mathrm{N}\right.$ Lat, $7^{\circ} 25^{\prime} \mathrm{E}$ Long, alt $80 \mathrm{~m}$ ). Site is believed to be far enough from domestic and industrial fuel sources.

\begin{tabular}{llll} 
MC-66. & Aug. & 1962 & $\delta C^{14 \%} \%$ \\
MC-67. & Dec. & $\mathbf{1 9 6 2}$ & $\mathbf{3 4 9} \pm \mathbf{1 0}$ \\
MC-69. & Aug. & 1963 & $\mathbf{7 5 4} \pm \mathbf{1 0}$ \\
\hline
\end{tabular}




$\begin{array}{llll}\text { MC-70. } & \text { May } & \mathbf{1 9 6 4} & \mathbf{9 5 7} \pm \mathbf{1 5} \\ \text { MC-71. } & \text { Aug. } & \mathbf{1 9 6 4} & \mathbf{8 5 0} \pm \mathbf{1 5} \\ \text { MC-72. } & \text { Nov. } & \mathbf{1 9 6 4} & \mathbf{8 2 8} \pm \mathbf{1 5} \\ \text { MC-73. } & \text { Nov. } & \mathbf{1 9 6 4} & \mathbf{7 4 0} \pm \mathbf{1 5} \\ \text { MC-74. } & \text { Feb. } & \mathbf{1 9 6 5} & \mathbf{7 5 1} \pm \mathbf{1 5} \\ \text { MC-75. } & \text { May } & \mathbf{1 9 6 5} & \mathbf{8 0 9} \pm \mathbf{1 5} \\ \text { MC-76. } & \text { Aug. } & \mathbf{1 9 6 5} & \mathbf{8 1 4} \pm \mathbf{1 5}\end{array}$

MC-72 was coll. on top of Mont Agel (43 $46^{\prime} \mathrm{N}$ Lat, $7^{\circ} 25^{\prime} \mathrm{E}$ Long, alt $1095 \mathrm{~m})$, far from houses, roads and factory smoke, to compare with MC-73, coll. near sealevel. Comment: results are in close agreement with those published by other labs. (Uppsala VI, UCLA IV).

\section{Modern organisms series}

MC-77. Modern organisms $1 \quad \delta \mathbf{C}^{14}=+751 \pm 15 \%$ o Buds of sea-pines grown near sealevel in Monaco. Coll. June 1965.

MC-58. Modern organisms $2 \quad \delta \mathbf{C}^{14}=+93 \pm 10 \%$ o

Shells of Mytilus galloprovincialis. Coll. alive March 1964 on rocks of Cape Martin at sealevel $\left(43^{\circ} 45^{\prime} \mathrm{N}\right.$ Lat, $7^{\circ} 29^{\prime} \mathrm{E}$ Long) .

\section{MC-80. Modern organisms 3}

$\delta \mathbf{C}^{14}=+113 \pm 10 \%$ o

Bryozoan: Retepora cellulosa. Coll. July 1965 by diving near Musée de Monaco at $35 \mathrm{~m}$ depth.

General Comment: measurements are part of a work intended to determine relative rapidity of $\mathrm{C}^{14}$ transfer from air into terrestrial plants and shallow-water marine organisms.

Date lists:

\section{REFERENCES}

Saclay I Delibrias, Guillier and Labeyrie, 1964

Saclay II Delibrias, Guillier and Labeyrie, 1965

UCLA IV Berger, Fergusson and Libby, 1965

Uppsala VI Olsson and Karlen, 1965

Blanchard, R., 1958, Annecy, essai de géographie humaine, ed. by Soc. des Amis du Vieil Annecy, I Rue Camille-Dunant, Annecy.

Fevret, M., and Sanlaville, P., 1965, Contribution à l'étude du littoral libanais: Méditerranée, no. 2, p. 114-132.

Gennesseaux, M., 1963, Structure et morphologie de la pente continentale de la région niçoise: Rapports et Procès Verbeaux des Réunions de la CIESM, v. 17, no. 3, p. $991-998$.

Movius, H., 1960, Radiocarbon dates and Upper Palaeolithic archaeology in central and western Europe: Current Anthropol., v. 1, no. 5-6, p. 336-391.

Nydal, R., 1960, Increase in radiocarbon from the most recent series of thermonuclear tests: Nature, v. 200, no. 4902 , p. 212-214.

Perès, J. M., and Picard, J., 1964, Nouveau manuel de bionomie benthique de la mer Méditerranée: Rec. Trav. St. Mar. Endoume, v. 47, no. 31, p. 16-19.

Thommeret, J., and Thommeret, Y., 1964, Validité de la datation des sédiments du proche quaternaire par le dosage du carbone 14 dans les coquilles: Rapports et Procès Verbaux des Réunions de la CIESM, v. 28, no. 3, in press.

Thommeret, J., Thommeret, Y., and Galliot, J., 1965, Teneur en radiocarbone des eaux profondes et superficielles du nord de l'océan Indien: Bull. de l'Inst. Océanog. Monaco, v. 65, no. 1347. 